\title{
Behavioural and chemical evidence for multiple colonisation of the Argentine ant, Linepithema humile, in the Western Cape, South Africa
}

\author{
Natasha P Mothapo*, Theresa C Wossler
}

\begin{abstract}
Background: The Argentine ant, Linepithema humile, is a widespread invasive ant species that has successfully established in nearly all continents across the globe. Argentine ants are characterised by a social structure known as unicoloniality, where territorial boundaries between nests are absent and intraspecific aggression is rare. This is particularly pronounced in introduced populations and results in the formation of large and spatially expansive supercolonies. Although it is amongst the most well studied of invasive ants, very little work has been done on this ant in South Africa. In this first study, we investigate the population structure of Argentine ants in South Africa. We use behavioural (aggression tests) and chemical (CHC) approaches to investigate the population structure of Argentine ants within the Western Cape, identify the number of supercolonies and infer number of introductions.

Results: Both the aggression assays and chemical data revealed that the Western Cape Argentine ant population can be divided into two behaviourally and chemically distinct supercolonies. Intraspecific aggression was evident between the two supercolonies of Argentine ants with ants able to discriminate among conspecific non-nestmates. This discrimination is linked to the divergence in cuticular hydrocarbon profiles of ants originating from the two supercolonies.

Conclusions: The presence of these two distinct supercolonies is suggestive of at least two independent introductions of this ant within the Western Cape. Moreover, the pattern of colonisation observed in this study, with the two colonies interspersed, is in agreement with global patterns of Argentine ant invasions. Our findings are of interest because recent studies show that Argentine ants from South Africa are different from those identified in other introduced ranges and therefore provide an opportunity to further understand factors that determine the distributional and spread patterns of Argentine ant supercolonies.
\end{abstract}

\section{Background}

Many species have been accidentally introduced into areas outside their geographic distribution as a direct consequence of human trade [1]. Indeed, the influx of exotic species has significantly increased globally with increased trade, highlighting the important role of human activity as a major driver of biological invasions [2-4]. Once established, invasive species have wide ranging impacts on the ecosystem including the displacement of native biota, disruption of ecosystem function in natural systems [5-7] as well as severe economic

\footnotetext{
* Correspondence: mothapo@sun.ac.za

DST/NRF Centre of Excellence for Invasion Biology, Department of Botany and Zoology, University of Stellenbosch, Private Bag X1, Matieland, 7602,
} South Africa

impacts in agriculture and forestry sectors [8]. Thus, invasive species are considered amongst the most significant threats to biodiversity globally [9].

Ants are regarded among the most damaging of invasive species largely due to the important roles they play in ecosystems globally [10-14]. Indeed five ant species are listed amongst the top 100 worst invaders in the world [12] and many have already established in most continents on the globe $[15,16]$. Although many of these ants show strong affinity for human modified habitats where there is high resource availability and limited biotic resistance [17], several have successfully penetrated into natural communities $[10,16,18,19]$.

The Argentine ant, Linepitheman humile, originates from South America and has successfully established on 
six continents and several oceanic islands. Their colony structure is the best studied of invasive ant species [20-24]. Similar to other invasive ants, Argentine ants are characterised by a social structure known as unicoloniality, where territorial boundaries are absent and intraspecific aggression between physically separate nests is rare [25-29]. Introduced populations form supercolonies that extend over thousands of kilometres [20,22,24,30-32] compared to their native range [33,34]. Ants from spatially separate nests within a supercolony treat each other as nestmates; however, ants from different supercolonies show pronounced aggression [20,30,35-37]. It is well established that aggression between ants from different colonies is determined by genetic similarity and similarity in cuticular hydrocarbon profiles $(\mathrm{CHC})[23,29]$, which represent recognition signals in ants and other insects [30,38-40].

Argentine ants in the introduced ranges are characterised by widespread acceptance of non-nestmate conspecifics, chemical and genetic similarity amongst distant populations $[20,23,25,30,31,35,41]$. Thus, mutually tolerant supercolonies sharing both chemical ( $\mathrm{CHC}$ profiles) and genetic similarity are expected to originate from the same source colonies in the native range $[34,41]$. This knowledge has been widely used to ascertain supercolony identity in both native and introduced ranges of the Argentine ant $[22,31,34,35,41,42]$, and has more recently been used to investigate introduction history of these ants and other invasive ants $[22,43,44]$. Several studies on the population structure of Argentine ants in most parts of the introduced range revealed the presence of multiple supercolonies, usually a single large supercolony with smaller supercolonies $[30,36]$. The presence of different supercolonies within a geographic area is thought to indicate multiple introduction events $[35,44]$. We use a combination of behavioural (aggression bioassays) and chemical (cuticular hydrocarbons) approaches to investigate the population structure of Argentine ants in the Western Cape, South Africa. Supercolony boundaries have been determined at local scales in both native and introduced ranges $[20,22,30-34,41]$, and more recently across continents $[24,41,45]$ however, this is not true for South Africa.

Since introduction into the Western Cape, South Africa in the early 1900s [46], Argentine ants have successfully spread throughout the region in both urban and natural environments $[47,48]$. The impacts of the invasion on the Fynbos biome of South Africa, a biodiversity hotspot, are similar to other introduced areas [49-51]. Argentine ants displace native ants and other arthropod fauna [52,53], disrupting important plant-ant interactions [54] and leading to the alteration of ecosystem functioning and cascading effects on other trophic levels [55]. Previous studies suggest that the Argentine ant has colonised South Africa multiple times, however, very little work has been done on this ant in South Africa and large scale data is lacking despite its clear importance. Tsutsui et al., (2001) found that Argentine ants from three localities in the Western Cape, South Africa, form two genetically different groups. This suggested that Argentine ants have been multiply introduced into South Africa and that more than one supercolony exists. Recently, Vogel et al. (2010) and Van Wilgenburg et al. (2010) showed that ants from Stellenbosch do not form part of the global large supercolony as identified in both these studies. Thus, the aims of this study are to [1] determine the population structure of Argentine ants within the Western Cape, South Africa (the point of entry for this ant); [2] to identify the number of supercolonies within this region, infer the number of introduction and relate the findings with what is observed in other introduced ranges.

\section{Methods}

\section{Collection of Argentine ants}

Argentine ants were collected from eight sites in the Western Cape region of South Africa: Stellenbosch, Somerset West, Jonkershoek, Bellville, Caledon, Bredasdorp, Elim and Porterville from September to October 2007 (Table 1, Figure 1). The sites sampled ranged over $900 \mathrm{~km}$ from the northern to the southern part of the Western Cape. For each site, we collected three nests (consisting of queens, workers and brood) at least $500 \mathrm{~m}$ apart to avoid collecting ants from the same nests. Nests were collected in plastic containers $(30 \mathrm{~cm} \times 2 \mathrm{~cm} \times 8 \mathrm{~cm})$ lined with Fluon (Fluoropolymer Dispersion, Whitford Plastics Ltd, England) one quarter down from the brim to prevent ants escaping. Prior to behavioural assays, ants were provided with $0.25 \mathrm{M}$ sugar water only.

\section{Behavioural assays}

Individual ants were paired from the same nest (controls), between nests within the same site as well as between nests from different sites. Pairwise aggression tests, adapted from earlier studies $[20,25,30]$ were used to assess the pattern of intraspecific aggression among Argentine ants within the Western Cape. Single, randomly picked workers from each of the two nests were paired in an $8 \mathrm{ml}$ glass pill vial lined with Fluon (one quarter down from the brim). Behavioural interactions between the two ants were observed and recorded over 10 minutes and scored according to escalating aggression on a scale from 0 - 4. Behavioural interactions were categorised as follows: 0 - ignore, 1 - antennate with no aggressive response, 2 - retract or avoidance, 3 - aggression (such as biting, lunging, pulling and mandible gaping) and 4 - prolonged aggression or fighting. Categories 0 to 2 were regarded as non-aggressive while 3 and 4 were aggressive [25]. For each nest pair, the behavioural assay was repeated ten times while each 
Table 1 Collection sites for Argentine ants in the Western Cape, South Africa

\begin{tabular}{|c|c|c|}
\hline Nest & Latitude & Longitude \\
\hline Stellenbosch 1 & $33^{\circ} 55.945^{\prime}$ & $018^{\circ} 51.825^{\prime}$ \\
\hline Stellenbosch 2 & $33^{\circ} 55.746^{\prime}$ & $018^{\circ} 51.889^{\prime}$ \\
\hline Stellenbosch 3 & $33^{\circ} 55.959^{\prime}$ & $018^{\circ} 51.990^{\prime}$ \\
\hline Bellville 1 & $33^{\circ} 55.940^{\prime}$ & $018^{\circ} 51.609^{\prime}$ \\
\hline Bellville 2 & $33^{\circ} 54.132^{\prime}$ & $018^{\circ} 37.593^{\prime}$ \\
\hline Bellville 3 & $33^{\circ} 52.346^{\prime}$ & $018^{\circ} 38.200^{\prime}$ \\
\hline Porterville 1 & $33^{\circ} 00.683^{\prime}$ & $019^{\circ} 00.511^{\prime}$ \\
\hline Porterville 2 & $32^{\circ} 59.072^{\prime}$ & $018^{\circ} 01.457^{\prime}$ \\
\hline Porterville 3 & $32^{\circ} 59.078^{\prime}$ & $019^{\circ} 01.392^{\prime}$ \\
\hline Elim 1 & $34^{\circ} 35.547^{\prime}$ & $019^{\circ} 45.589^{\prime}$ \\
\hline Elim 2 & $34^{\circ} 35.277^{\prime}$ & $019^{\circ} 45.445^{\prime}$ \\
\hline Elim 3 & $34^{\circ} 31.751^{\prime}$ & $019^{\circ} 50.112^{\prime}$ \\
\hline Bredasdorp 1 & $34^{\circ} 32.258^{\prime}$ & $020^{\circ} 02.760^{\prime}$ \\
\hline Bredasdorp 2 & $34^{\circ} 32.607^{\prime}$ & $020^{\circ} 02.892^{\prime}$ \\
\hline Bredasdorp 3 & $34^{\circ} 31.830^{\prime}$ & $020^{\circ} 02.106^{\prime}$ \\
\hline Caledon 1 & $34^{\circ} 14.355^{\prime}$ & $019^{\circ} 25.699^{\prime}$ \\
\hline Caledon 2 & $34^{\circ} 13.616^{\prime}$ & $019^{\circ} 24.561^{\prime}$ \\
\hline Caledon 3 & $34^{\circ} 14.045^{\prime}$ & $019^{\circ} 25.175^{\prime}$ \\
\hline Somerset west 1 & $34^{\circ} 04.173^{\prime}$ & $018^{\circ} 49.810^{\prime}$ \\
\hline Somerset west 2 & $34^{\circ} 05.045^{\prime}$ & $018^{\circ} 49.326^{\prime}$ \\
\hline Somerset west 3 & $34^{\circ} 04.669^{\prime}$ & $018^{\circ} 50.717^{\prime}$ \\
\hline Jonkershoek 1 & $33^{\circ} 58.819^{\prime}$ & $018^{\circ} 56.738^{\prime}$ \\
\hline Jonkershoek 2 & $33^{\circ} 59.482^{\prime}$ & $018^{\circ} 57.251^{\prime}$ \\
\hline Jonkershoek 3 & $33^{\circ} 58.733^{\prime}$ & $018^{\circ} 56.982^{\prime}$ \\
\hline
\end{tabular}

List and GPS coordinates of field sites where Argentine ants were collected.

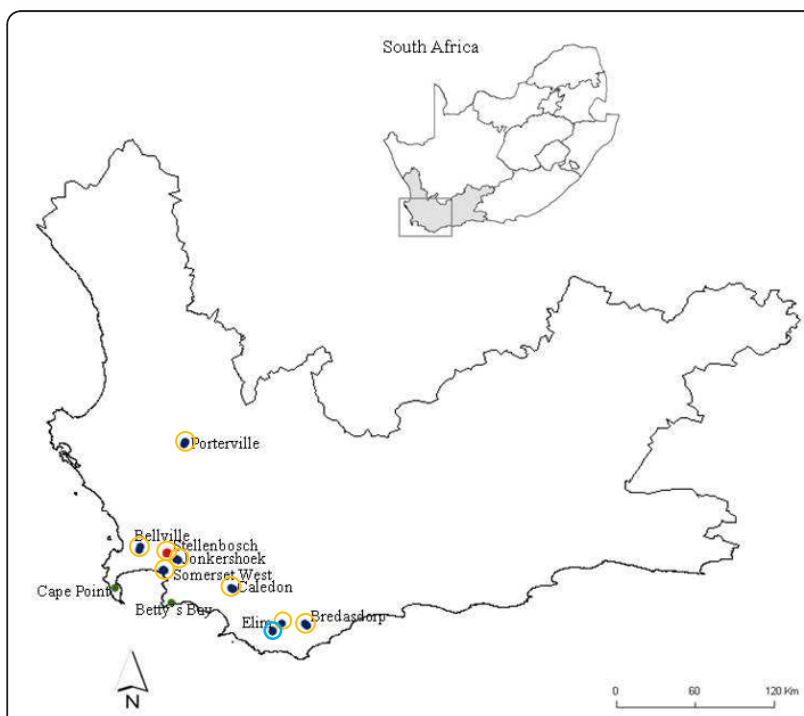

Figure 1 Map of Western Cape, South Africa and the sites used in this study. Map of the Western Cape region, South Africa with the eight sites from which Argentine ants were collected for this study, including sites from previous studies ("green circle") Tsutsui et al., 2001 (Cape point, Betty's Bay and Caledon); ("red circle") Vogel et al., 2010 (Stellenbosch) and Van Wilgenburg et al., 2010 (Stellenbosch). Ants were collected from Porterville in the North right down to Elim in the South. worker was used only once. The nest origin was unknown to the observer.

\section{Chemical analyses}

Ten workers from the same nest were washed in $100 \mu \mathrm{l}$ of hexane for 10 minutes, followed by a second two minute rinse in another $100 \mu \mathrm{l}$ of hexane. The two samples were combined to produce a $200 \mu \mathrm{l}$ cuticular lipid extract. To purify the extract, silica gel minicolumns were constructed from glass Pasteur pipette tubes filled with $\pm 500 \mathrm{mg}$ of silica gel (grade 13,30-200 mesh, SIGMA-Aldrich, USA), plugged with glass wool and pre-wetted with $2 \mathrm{ml}$ hexane prior to loading the cuticular lipid extract (here forth, $\mathrm{CHC}$ extract) [56-59]. The $\mathrm{CHC}$ extract was concentrated under a stream of nitrogen to $100 \mu \mathrm{l}$ and then loaded onto the pre-wetted silica gel minicolumn. The hydrocarbon fraction was eluted with $3 \mathrm{ml}$ of hexane, evaporated to dryness under a stream of nitrogen and redissolved in $25 \mu \mathrm{l}$ hexane. A volume of $1 \mu \mathrm{l}$ of the extract was injected in a Gas Chromatograph (Agilent3850) fitted with a splitless inlet, flame-ionisation detection and a DB-5 capillary column $(30 \mathrm{~m} \times 0.32 \mathrm{~mm} \times 0.25 \mu \mathrm{m}$ film thickness, Agilent Technologies, CA). The injection port and the detector were set at $290^{\circ} \mathrm{C}$ and $320^{\circ} \mathrm{C}$, respectively. Helium was used as the carrier gas at $30.4 \mathrm{ml} / \mathrm{min}$ and nitrogen as the make-up gas. The following temperature program was used: oven temperature was held at $80^{\circ} \mathrm{C}$ for 2 minutes, and then increased to $270^{\circ} \mathrm{C}$ at a rate of $10^{\circ} \mathrm{C} / \mathrm{min}$ then raised to $310^{\circ} \mathrm{C}$ at $3^{\circ} \mathrm{C} / \mathrm{min}$ and finally held at $310^{\circ} \mathrm{C}$ for 20 minutes. Electron impact mass spectra (Agilent 5975B mass spectrometer) were used as the means of identifying the peaks (compounds) on the chromatograms. The compounds were identified by comparing their mass spectra with those of pure compounds accessed via the WILEY and NIST (National Institute of Standards and Technology) databases. Only compounds with a match of $90 \%$ or more to those accessed in the library were positively identified. All compounds in trace quantities were not included because their abundances could not be calculated.

\section{Statistical analyses Behavioural assays}

Behavioural categories were converted to binary data, aggression vs. non-aggression. In many behavioural studies, the scores are averaged to get a single number or aggression index that is thought to represent the level of aggression per nest pair in each trial $[25,60]$; and used to statistically analyse the data. However, converting categorical data into mean behavioural or aggression indices is thought to conceal some subtle behavioural differences between trials [42]. Therefore, two non-parametric approaches were used to analyse the behavioural data: (i) Chi-square tests were used 
to compare aggression between nestmates and non-nestmates within sites. (ii) Multivariate data analyses were performed in PRIMER (Plymouth Routines in Multivariate Ecological Research, version 5.2.9, 2004: Plymouth Marine Laboratory, UK) to assess the differences in the level of aggressive interactions for nests between sites. An ordination analysis was conducted using non-metric Multidimensional Scaling (hereafter MDS) plots that score and display categories based on their similarity or dissimilarity [61]. The stress value on the MDS plot is a measure of the goodness of fit and is dependent on the dimensions of the data used. A stress value below 0.7 is an indication of a good fit [62]. Bray-Curtis coefficients were used to calculate the similarity matrix [63] and an Analysis of Similarity (ANOSIM) test, based on 1000 permutations, was used to assess the significance of the separation of aggressive interactions between the groups on the MDS plot. Global R values closer or equal to zero indicate strong similarity between the test groups and those closer to or equal to one indicate very strong differences between the test groups. Statistical significance was accepted at $\mathrm{p}<0.05$.

\section{Chemical analyses}

Forty cuticular compounds were separated and identified by Gas Chromatography/Mass Spectrometry (GC/ MS), and the peak areas were standardised to $100 \%$ by calculating the percentage contribution of each compound to the cuticular hydrocarbon blend. The proportion of the relative compounds was calculated as the ratio of that compound relative to the other 39 compounds. Because peak areas represent compositional data, the standardised peak areas were transformed to logcontrasts using Aitchison's (1986) [64] formula: $\mathrm{Z}_{\mathrm{ij}}=\ln \left[\mathrm{Y}_{\mathrm{ij}} / \mathrm{g}\left(\mathrm{Y}_{\mathrm{j}}\right)\right]$, where $\mathrm{Z}_{\mathrm{ij}}$ is the standardised peak area $i$, for individual $j, \mathrm{Y}_{\mathrm{ij}}$ is the peak area $i$ for individual $j$, and $g\left(Y_{j}\right)$ is the geometric mean of all peaks for individual $j$. Multivariate data analyses were performed using SPSS 17.0 software. The standardised peak areas were subjected to a Principal Components Analysis (PCA), with varimax rotation, to reduce the number of describing variables. The extracted PCA factors were further subjected to a Discriminant Analysis (DA) to determine whether the behaviourally defined Argentine ant colonies could also be discriminated on the basis of their $\mathrm{CHC}$ profiles.

\section{Results}

\section{Behavioural Assays}

Aggression tests revealed that Argentine ants within the Western Cape are unicolonial, as ants from distant sites were mutually tolerant. Intraspecific aggression was rare between ants from the same site (Figure 2). One nest in Elim, Elim 3, was aggressive to all other nests within this site (Elim 1 and Elim 2; Figure 2).Consequently; two nests (Elim 2 - non-aggressive; Elim 3 - aggressive) were selected

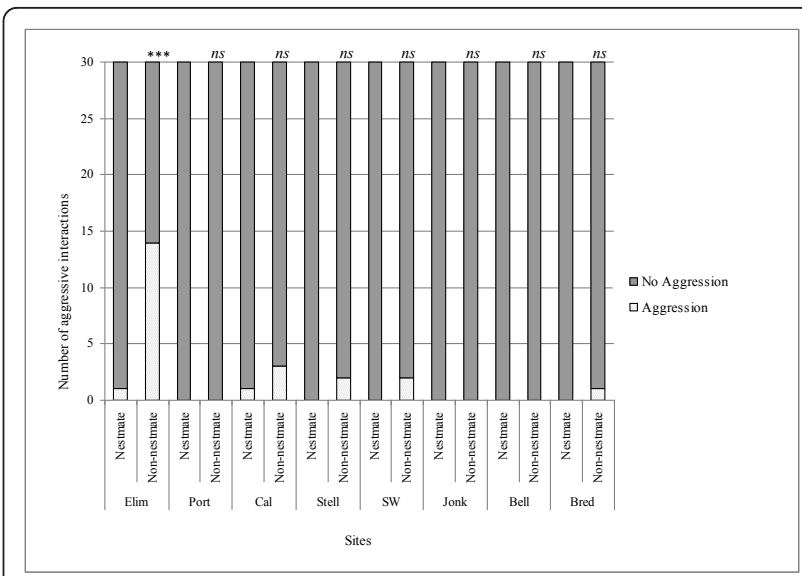

Figure 2 Behavioural interactions of Argentine ants within sites. Frequency of aggressive and non-aggressive behavioural interactions between nestmates and non-nestmates within each site. The frequency represents the total number of interactions (aggressive and non-aggressive) of all three nests within a site for within and between nest interactions observed over 10 minutes. Levels of significance shown by (ns) $P>0.05$ and $\left(^{* *}\right) P<0.001$ (Chi-Square test). Locality abbreviations: Elim = Elim, Port $=$ Porterville, $\mathrm{Cal}=$ Caledon, Stell $=$ Stellenbosch, SW = Somerset West, Jonk = Jonkershoek, Bell = Bellville, and Bred = Bredasdorp.

and treated independently in further analyses. There was very little aggression observed between ants from different sites despite large geographic distances separating them (Table 2). Only interactions that included ants from Elim resulted in significantly high levels of injurious aggression (Table 2). The MDS revealed two groups, those interactions including ants from Elim 3 and those that did not (Global $\mathrm{R}=0.982$, $\mathrm{p}<0.001$; Figure 3 ), suggesting that a behavioural boundary exists between ants from Elim 3 and all the other sites included in this study. In assays between non-aggressive non-nestmates, ants spent most of their time antennating or self-grooming. Furthermore, these data show no relationship between aggression and distance between nests, since ants remained non-aggressive despite large geographical distances separating them (see Figure 1).

\section{Chemical analyses}

Forty compounds were separated and thirty eight of them identified in the $\mathrm{CHC}$ profile of field populations of Argentine ant (see Table 3 for compound identification). The profiles are characterised by a series of linear alkanes (retention times 9-28 mins) followed by clusters of long-chained and methyl-branched hydrocarbons (retention times 30-38 mins) (Figure 4) with chainlengths ranging from $\mathrm{C}_{13}-\mathrm{C}_{44}$ (Table 3 ). Saturated longchained hydrocarbons, namely, hexacosane, heptacosane and octacosane were the most abundant compounds in the profiles of ants from Stellenbosch, while 13-methylhentriacontane was abundant in the profiles of ants 
Table 2 Aggressive interactions between ants from different sites

\begin{tabular}{|c|c|c|c|c|c|c|c|c|c|}
\hline & SW & Cal & Stel & EL3 & EL2 & Port & Jonk & Bell & Bred \\
\hline \multicolumn{10}{|l|}{ SW } \\
\hline Cal & $1 / 10^{\mathrm{ns}}$ & & & & & & & & \\
\hline Stel & $0 / 10^{\text {ns }}$ & $0 / 10^{\text {ns }}$ & & & & & & & \\
\hline El3 & $7 / 10^{* * *}$ & $7 / 10^{* * *}$ & $8 / 10^{* * *}$ & & & & & & \\
\hline EL2 & $3 / 10^{*}$ & $4 / 10^{*}$ & $0 / 10^{\text {ns }}$ & $9 / 10^{* * *}$ & & & & & \\
\hline Port & $0 / 10^{\text {ns }}$ & $0 / 10^{\text {ns }}$ & $0 / 10^{\text {ns }}$ & $8 / 10^{* * *}$ & $1 / 10^{\text {ns }}$ & & & & \\
\hline Jonk & $1 / 10^{\mathrm{ns}}$ & $0 / 10^{\text {ns }}$ & $0 / 10^{\text {ns }}$ & $9 / 10^{* * *}$ & $4 / 10^{*}$ & $0 / 10^{\text {ns }}$ & & & \\
\hline Bell & $1 / 10^{\mathrm{ns}}$ & $0 / 10^{\text {ns }}$ & $0 / 10^{\text {ns }}$ & $6 / 10^{* *}$ & $0 / 10^{\text {ns }}$ & $0 / 10^{\text {ns }}$ & $0 / 10^{\text {ns }}$ & & \\
\hline Bred & $1 / 10^{\mathrm{ns}}$ & $2 / 10^{\mathrm{ns}}$ & $0 / 10^{\text {ns }}$ & $8 / 10^{* * *}$ & $3 / 10^{*}$ & $0 / 10^{\text {ns }}$ & $0 / 10^{\text {ns }}$ & $0 / 10^{\text {ns }}$ & \\
\hline
\end{tabular}

Frequency of aggression between ants from different sites. Levels of significance based on Chi-Square test shown by (ns) $\mathrm{P}>0.05,\left({ }^{*}\right) \mathrm{P}<0.05,\left({ }^{* *}\right) \mathrm{P}<0.01$ and $(* * *) \mathrm{P}<0.001$. Degrees of Freedom $(d f=1)$. Site abbreviations: SW $=$ Somerset West, Cal $=$ Caledon, Stel $=$ Stellenbosch, EL3 $=$ Elim 3, EL2 $=$ Elim 2, Jonk $=$ Jonkershoek, Bell = Bellville and Bred = Bredasdorp.

from Porterville and Bredasdorp. The cuticular profiles of ants from Elim 3 are distinguishable from all other sites in that Elim 3 ants have high abundances of the two unknown compounds (peaks 35 and 40) and low abundances of tetratriacontane (peak 24) and heptatriacontane (peak 28) in contrast to other samples (Table 3).

The PCA produced nine principal components (PC) with eigenvalues larger than 1 , explaining $74.5 \%$ of the total variance. A DA on these principal components significantly separated the Argentine ants into two groups based on the CHC profiles (Wilks' $\lambda=0.034 \chi^{2}=$ 46.86 d.f. $=72 P<0.0001$, Figure 5). The ants from Elim 3 nest were the most aggressive, and they showed strong chemical divergence from all other ants used in this study (Figure 5). In the classification results of the DA,

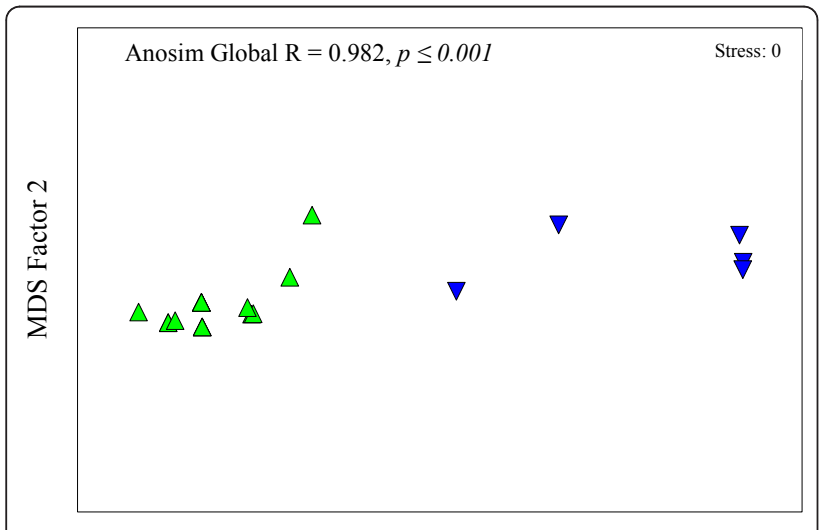

MDS Factor 1

Figure 3 Behavioural interactions of Argentine ants from different sites. Non-metric Multidimensional Scaling (MDS) plot showing all aggressive and non-aggressive behavioural interactions for paired nests between sites. Analyses were conducted using the categories aggression and non-aggression. The separation incorporated colony interactions that included Elim 3 and those that did not. All interactions that included Elim 3 ("green triangle") and those that excluded Elim 3 ("blue trianlgle") grouped separately indicating a distinct boundary between Elim and all other sites.
$57.4 \%$ of all CHC samples were correctly assigned to their respective groups and all Elim 3 ants were 100\% correctly classified into their group. The ants from the different sites were separated along the Discriminant Function 1, and the compounds associated with this separation are the straight chained alkanes tetratriacontane and heptatriacontane, the methyl-branched alkanes 17-methylheptatriacontane and 13,17,21-trimethylheptatriacontane, as well as an unknown compound (peak 35, see Table 3).

\section{Discussion}

This study is the first investigation of the population structure of Argentine ants in the Western Cape, South Africa using behavioural and chemical analyses. The chemical and behavioural data revealed that Argentine ants within the Western Cape are unicolonial and indicated the presence of at least two supercolonies that come into contact at Elim. Throughout this study ants were rarely aggressive to each other, except for all the interactions that included ants from Elim 3 where these ants were both behaviourally and chemically dissimilar from all other ants used in this study. These data are in keeping with the findings published on Argentine ant behaviour whereby ants from different supercolonies attack each other [20,22,30,33,42].

The CHC profiles of Argentine ants within the Western Cape consisted of the structural hydrocarbon classes found and identified in previous nestmate recognition studies of this ant $[23,58]$. We found that marked differences in CHC profiles, particularly for Elim 3 nest (Figure 5), resulted in maximum aggression, supporting the prediction that there is a negative relationship between chemical similarity and intraspecific aggression [55-58].

Argentine ant populations in the introduced ranges are characterised by widespread acceptance of non-nestmate conspecifics and genetic similarity among distant populations $[20,23,30,31]$ as well as chemical resemblance across 
Table 3 List of Compounds found in CHC profiles of Argentine ants

\begin{tabular}{|c|c|c|c|c|c|c|c|c|c|c|}
\hline Peak & Compound & $\operatorname{Elim}_{(1+2)}$ & Elim 3 & Bell & Stell & Cal & Port & SW & Bredas & Jonk \\
\hline 1 & Tridecane & $1.83 \pm 0.45$ & $2.07 \pm 0.60$ & $1.73 \pm 0.48$ & $1.33 \pm 0.75$ & $2.50 \pm 0.96$ & $2.19 \pm 0.54$ & $2.14 \pm 0.63$ & $3.06 \pm 0.59$ & $2.75 \pm 0.41$ \\
\hline 2 & Tetradecane & $0.33 \pm 0.22$ & $0.44 \pm 0.11$ & $0.34 \pm 0.19$ & 0.00 & $0.06 \pm 0.07$ & $0.56 \pm 0.28$ & $0.66 \pm 0.27$ & $0.58 \pm 0.21$ & $0.46 \pm 0.21$ \\
\hline 3 & Hexadecane & $0.80 \pm 0.18$ & $0.74 \pm 0.17$ & $0.28 \pm 0.11$ & $0.35 \pm 0.25$ & $0.87 \pm 0.42$ & $0.39 \pm 0.27$ & $0.73 \pm 0.19$ & $0.38 \pm 0.20$ & $0.79 \pm 0.22$ \\
\hline 4 & Heptadecane & $0.29 \pm 0.13$ & $0.47 \pm 0.10$ & $0.36 \pm 0.10$ & 0.00 & $0.18 \pm 0.13$ & 0.00 & $0.61 \pm 0.19$ & $0.70 \pm 0.26$ & $0.93 \pm 0.33$ \\
\hline 5 & Octadecane & $0.03 \pm 0.03$ & $0.17 \pm 0.08$ & $0.10 \pm 0.06$ & 0.00 & $0.27 \pm 0.26$ & $0.26 \pm 0.46$ & $0.22 \pm 0.13$ & $0.18 \pm 0.11$ & 0.00 \\
\hline 6 & Nonadecane & $0.03 \pm 0.04$ & $0.24 \pm 0.08$ & $0.13 \pm 0.07$ & 0.00 & $0.24 \pm 0.22$ & $0.25 \pm 0.35$ & $0.18 \pm 0.11$ & $0.22 \pm 0.12$ & 0.00 \\
\hline 7 & Eicosane & $0.49 \pm 0.13$ & $0.63 \pm 0.04$ & $0.52 \pm 0.12$ & $0.18 \pm 0.17$ & $0.92 \pm 0.38$ & $0.66 \pm 0.73$ & $0.94 \pm 0.36$ & $0.62 \pm 0.26$ & $0.50 \pm 0.40$ \\
\hline 8 & Heneicosane & $0.79 \pm 0.17$ & $0.87 \pm 0.05$ & $0.94 \pm 0.07$ & $0.67 \pm 0.70$ & $1.08 \pm 0.62$ & $0.79 \pm 0.27$ & $2.05 \pm 0.63$ & $1.02 \pm 0.42$ & $0.64 \pm 0.23$ \\
\hline 9 & Docosane & $1.82 \pm 0.20$ & $1.52 \pm 0.11$ & $1.61 \pm 0.12$ & $2.04 \pm 0.71$ & $4.07 \pm 1.66$ & $2.00 \pm 0.29$ & $5.88 \pm 1.87$ & $2.53 \pm 1.18$ & $1.57 \pm 0.35$ \\
\hline 10 & Tricosane & $2.83 \pm 0.25$ & $2.43 \pm 0.19$ & $2.71 \pm 0.21$ & $4.27 \pm 1.10$ & $5.67 \pm 1.95$ & $3.15 \pm 0.47$ & $7.96 \pm 2.29$ & $3.87 \pm 1.32$ & $2.89 \pm 0.38$ \\
\hline 11 & Tetracosane & $4.11 \pm 0.29$ & $3.56 \pm 0.33$ & $3.80 \pm 0.30$ & $6.25 \pm 1.29$ & $7.78 \pm 2.28$ & $4.88 \pm 0.63$ & $10.15 \pm 2.62$ & $5.65 \pm 1.45$ & $4.23 \pm 0.52$ \\
\hline 12 & Pentacosane & $5.88 \pm 0.49$ & $4.66 \pm 0.35$ & $5.25 \pm 0.43$ & $6.51 \pm 2.55$ & $6.12 \pm 1.45$ & $6.41 \pm 0.81$ & $5.14 \pm 1.70$ & $5.83 \pm 1.04$ & $5.63 \pm 0.66$ \\
\hline 13 & 1,2,benzenedicarboxylic acid & $4.34 \pm 1.31$ & $2.08 \pm 0.30$ & $1.89 \pm 0.44$ & $1.53 \pm 1.01$ & $1.50 \pm 0.69$ & $2.01 \pm 0.67$ & $1.53 \pm 0.53$ & $3.10 \pm 1.03$ & $2.01 \pm 0.45$ \\
\hline 14 & Hexacosane & $5.51 \pm 0.43$ & $4.83 \pm 0.37$ & $5.17 \pm 0.34$ & $9.53 \pm 2.25$ & $7.19 \pm 1.46$ & $6.16 \pm 0.73$ & $8.33 \pm 1.01$ & $6.44 \pm 0.80$ & $5.21 \pm 0.62$ \\
\hline 15 & Heptacosane & $6.30 \pm 0.17$ & $6.94 \pm 0.42$ & $5.75 \pm 0.41$ & $10.88 \pm 2.73$ & $7.21 \pm 0.48$ & $5.71 \pm 0.63$ & $6.32 \pm 0.32$ & $5.96 \pm 0.88$ & $5.48 \pm 0.50$ \\
\hline 16 & Octacosane & $4.20 \pm 0.19$ & $4.18 \pm 0.25$ & $4.80 \pm 0.34$ & $7.38 \pm 1.79$ & $5.22 \pm 0.54$ & $4.92 \pm 0.79$ & $4.88 \pm 0.26$ & $4.76 \pm 0.52$ & $4.45 \pm 0.42$ \\
\hline 17 & Nonacosane & $4.43 \pm 0.24$ & $4.50 \pm 0.26$ & $4.99 \pm 0.38$ & $6.82 \pm 1.31$ & $4.82 \pm 0.45$ & $4.63 \pm 0.44$ & $4.27 \pm 0.40$ & $4.98 \pm 0.62$ & $4.46 \pm 0.40$ \\
\hline 18 & Triacontane & $3.36 \pm 0.24$ & $3.70 \pm 0.15$ & $4.41 \pm 0.60$ & $4.11 \pm 1.01$ & $3.75 \pm 0.45$ & $3.53 \pm 0.38$ & $3.05 \pm 0.26$ & $3.50 \pm 0.45$ & $3.48 \pm 0.49$ \\
\hline 19 & Hentriacontane & $3.04 \pm 0.23$ & $3.07 \pm 0.22$ & $3.73 \pm 0.44$ & $2.97 \pm 0.65$ & $3.15 \pm 0.42$ & $2.81 \pm 0.33$ & $2.67 \pm 0.34$ & $2.82 \pm 0.41$ & $3.13 \pm 0.31$ \\
\hline 20 & Dotriacontane & $2.72 \pm 0.23$ & $3.37 \pm 0.48$ & $3.60 \pm 0.58$ & $2.33 \pm 0.65$ & $2.77 \pm 0.42$ & $2.45 \pm 0.43$ & $2.23 \pm 0.28$ & $2.04 \pm 0.47$ & $2.90 \pm 0.25$ \\
\hline 21 & 13-methylhentriacontane & $0.03 \pm 0.04$ & $0.26 \pm 0.18$ & $0.51 \pm 0.41$ & $3.17 \pm 3.45$ & $0.44 \pm 0.36$ & $13.40 \pm 6.91$ & $1.18 \pm 0.94$ & $12.97 \pm 4.49$ & $3.38 \pm 2.64$ \\
\hline 22 & Tritriacontane & $2.04 \pm 0.19$ & $2.36 \pm 0.16$ & $2.45 \pm 0.34$ & $1.28 \pm 0.49$ & $2.05 \pm 0.34$ & $1.68 \pm 0.28$ & $1.88 \pm 0.30$ & $1.67 \pm 0.38$ & $2.11 \pm 0.19$ \\
\hline 23 & $2,6,10,15$ tetramethyl heptadecane & $2.75 \pm 0.21$ & $1.41 \pm 0.18$ & $2.78 \pm 0.28$ & $1.56 \pm 0.58$ & $1.82 \pm 0.60$ & $2.08 \pm 0.34$ & $1.89 \pm 0.46$ & $2.17 \pm 0.46$ & $1.88 \pm 0.34$ \\
\hline 24 & Tetratriacontane & $8.25 \pm 0.80$ & $0.33 \pm 0.11$ & $6.38 \pm 0.58$ & $7.06 \pm 2.44$ & $5.26 \pm 1.41$ & $7.71 \pm 1.59$ & $4.04 \pm 1.29$ & $4.47 \pm 1.11$ & $7.68 \pm 0.99$ \\
\hline 25 & Pentatriacontane & $1.64 \pm 0.29$ & $2.91 \pm 0.26$ & $2.95 \pm 0.46$ & $2.32 \pm 1.50$ & $2.63 \pm 0.77$ & $2.76 \pm 2.09$ & $1.35 \pm 0.42$ & $1.27 \pm 0.58$ & $2.32 \pm 0.82$ \\
\hline 26 & Hexatriacontane & $2.81 \pm 0.52$ & $1.33 \pm 1.33$ & $4.09 \pm 0.49$ & $3.03 \pm 1.02$ & $2.72 \pm 0.76$ & $2.77 \pm 0.52$ & $2.74 \pm 0.50$ & $2.34 \pm 0.45$ & $3.28 \pm 0.38$ \\
\hline 27 & $13,17,21$ trimethylpentatriacontane & $2.08 \pm 0.36$ & $1.62 \pm 1.62$ & $1.15 \pm 0.28$ & $0.40 \pm 0.35$ & $1.13 \pm 0.46$ & $1.19 \pm 0.38$ & $0.63 \pm 0.35$ & $1.36 \pm 0.47$ & $2.35 \pm 0.47$ \\
\hline
\end{tabular}


Table 3 List of Compounds found in CHC profiles of Argentine ants (Continued)

\begin{tabular}{|c|c|c|c|c|c|c|c|c|c|c|}
\hline 28 & Heptatriacontane & $1.81 \pm 0.21$ & $0.10 \pm 0.05$ & $1.32 \pm 0.21$ & $0.29 \pm 0.23$ & $0.78 \pm 0.35$ & $0.70 \pm 0.28$ & $0.83 \pm 0.35$ & $0.63 \pm 0.23$ & $1.52 \pm 0.32$ \\
\hline 29 & Octatriacontane & $1.64 \pm 0.24$ & $2.04 \pm 0.37$ & $1.99 \pm 0.29$ & $1.33 \pm 0.73$ & $1.35 \pm 0.37$ & $0.98 \pm 0.31$ & $1.35 \pm 0.28$ & $1.15 \pm 0.36$ & $1.57 \pm 0.21$ \\
\hline 30 & 17-methylheptatriacontane & $2.90 \pm 0.25$ & $2.19 \pm 0.21$ & $2.99 \pm 0.31$ & $1.76 \pm 1.08$ & $1.89 \pm 0.65$ & $1.50 \pm 0.37$ & $2.56 \pm 0.64$ & $1.94 \pm 0.57$ & $1.95 \pm 0.39$ \\
\hline 31 & 17, 21 dimethylheptatriacontane & $8.76 \pm 0.91$ & $1.90 \pm 0.67$ & $6.83 \pm 0.78$ & $3.45 \pm 1.26$ & $5.21 \pm 1.71$ & $4.97 \pm 0.87$ & $2.81 \pm 1.46$ & $4.01 \pm 0.99$ & $7.71 \pm 1.13$ \\
\hline 32 & $13,17,21$ trimethylheptatriacontane & $1.46 \pm 0.28$ & $2.68 \pm 1.21$ & $3.40 \pm 0.60$ & $2.00 \pm 0.89$ & $2.48 \pm 0.86$ & $1.62 \pm 0.37$ & $2.00 \pm 0.56$ & $1.74 \pm 0.53$ & $2.32 \pm 0.31$ \\
\hline 33 & Tritetraconatne & $2.24 \pm 0.19$ & $5.80 \pm 3.38$ & $3.23 \pm 0.58$ & $2.47 \pm 0.89$ & $2.48 \pm 0.48$ & $1.82 \pm 0.53$ & $2.24 \pm 1.34$ & $2.12 \pm 1.57$ & $4.84 \pm 1.16$ \\
\hline 34 & 13-methyltritetracontane & $0.70 \pm 0.20$ & 0.00 & $0.42 \pm 0.16$ & $0.07 \pm 0.11$ & $0.28 \pm 0.19$ & $0.17 \pm 0.17$ & $0.12 \pm 0.09$ & $0.46 \pm 0.20$ & $0.64 \pm 0.26$ \\
\hline 35 & unknown & $0.78 \pm 0.27$ & $6.45 \pm 0.61$ & $1.09 \pm 0.18$ & $0.45 \pm 0.33$ & $0.46 \pm 0.31$ & $0.14 \pm 0.13$ & $0.62 \pm 0.28$ & $0.68 \pm 0.29$ & $0.69 \pm 0.29$ \\
\hline 36 & Tetratetracontane & $0.92 \pm 0.11$ & $2.16 \pm 0.35$ & $0.92 \pm 0.20$ & $0.24 \pm 0.23$ & $0.49 \pm 0.26$ & $0.15 \pm 0.15$ & $0.97 \pm 0.28$ & $0.71 \pm 0.30$ & $0.54 \pm 0.21$ \\
\hline 37 & 1-bromotetratetracontane & $0.46 \pm 0.31$ & 0.00 & $0.65 \pm 0.39$ & $0.49 \pm 0.36$ & $0.85 \pm 0.40$ & $0.43 \pm 0.24$ & $0.98 \pm 0.29$ & $0.45 \pm 0.35$ & $1.23 \pm 0.35$ \\
\hline 38 & 13-methyltetratetracontane & $1.58 \pm 0.19$ & 0.00 & $1.40 \pm 0.11$ & $0.27 \pm 0.25$ & $0.46 \pm 0.29$ & $0.34 \pm 0.21$ & $0.88 \pm 0.39$ & $0.43 \pm 0.20$ & $1.33 \pm 0.25$ \\
\hline 39 & 13, 17 dimethyltetratetracontane & $1.30 \pm 0.28$ & $0.48 \pm 0.48$ & $1.17 \pm 0.39$ & $0.16 \pm 0.20$ & $0.63 \pm 0.56$ & $0.26 \pm 0.28$ & $0.07 \pm 0.12$ & 0.00 & $0.88 \pm 0.82$ \\
\hline 40 & unknown & $1.12 \pm 0.27$ & $7.77 \pm 2.58$ & $1.61 \pm 0.36$ & $1.06 \pm 0.59$ & $1.21 \pm 0.41$ & $1.57 \pm 0.86$ & $0.95 \pm 0.28$ & $1.21 \pm 0.50$ & $1.18 \pm 0.34$ \\
\hline
\end{tabular}

The 40 cuticular compounds identified and their percentage contribution (Mean + SE), in the cuticular lipid extract sampled from field populations of Argentine ants for the 8 sites. Three nests were sampled per site $(\mathrm{N}=18$ runs per site) . Elim $(1+2)=$ Elim, Elim $3=$ Elim 3, Bell = Bellville, Stell $=$ Stellenbosch, Cal = Caledon, Port $=$ Porterville, SW = Somerset West, Bredas $=$ Bredasdorp, Jonk $=$ Jonkershoek 


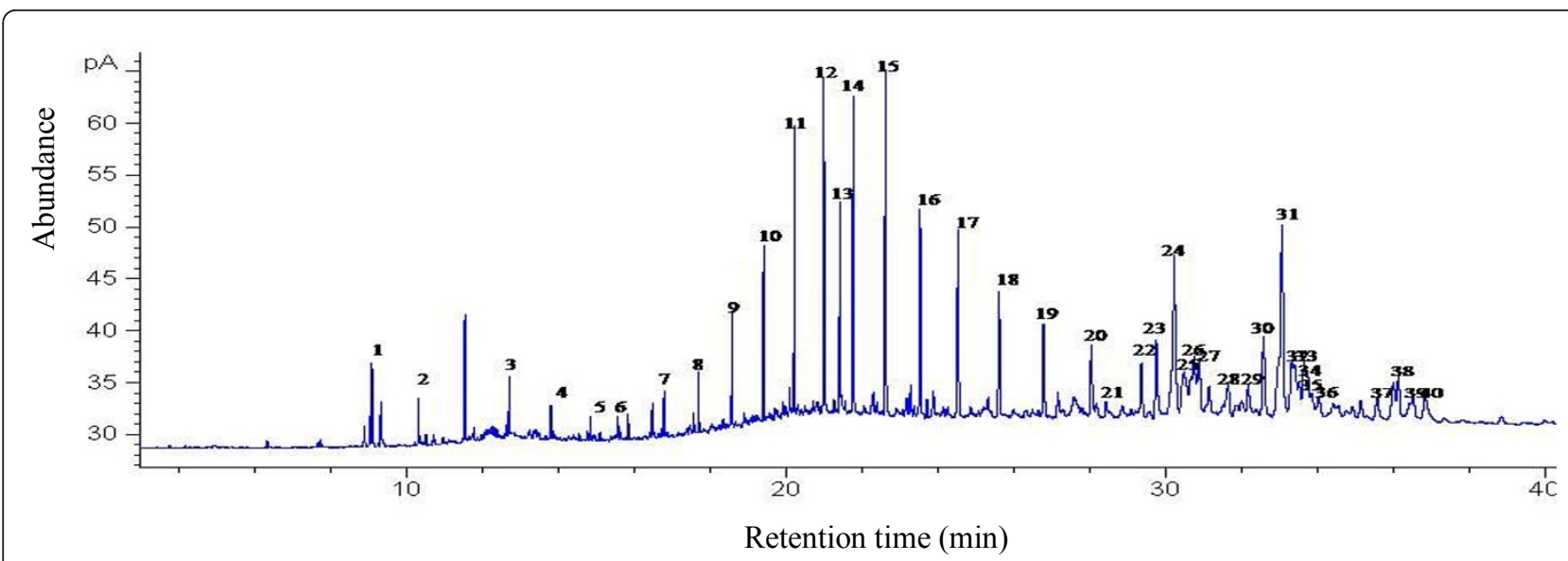

Figure 4 Chromatogram of Argentine ants from Western Cape, South Africa. A representative gas chromatogram of a cuticular hydrocarbon profile of field collected Argentine ants in the Western Cape. Chromatogram of Elim nest 2, See Table 1 for peak identification.

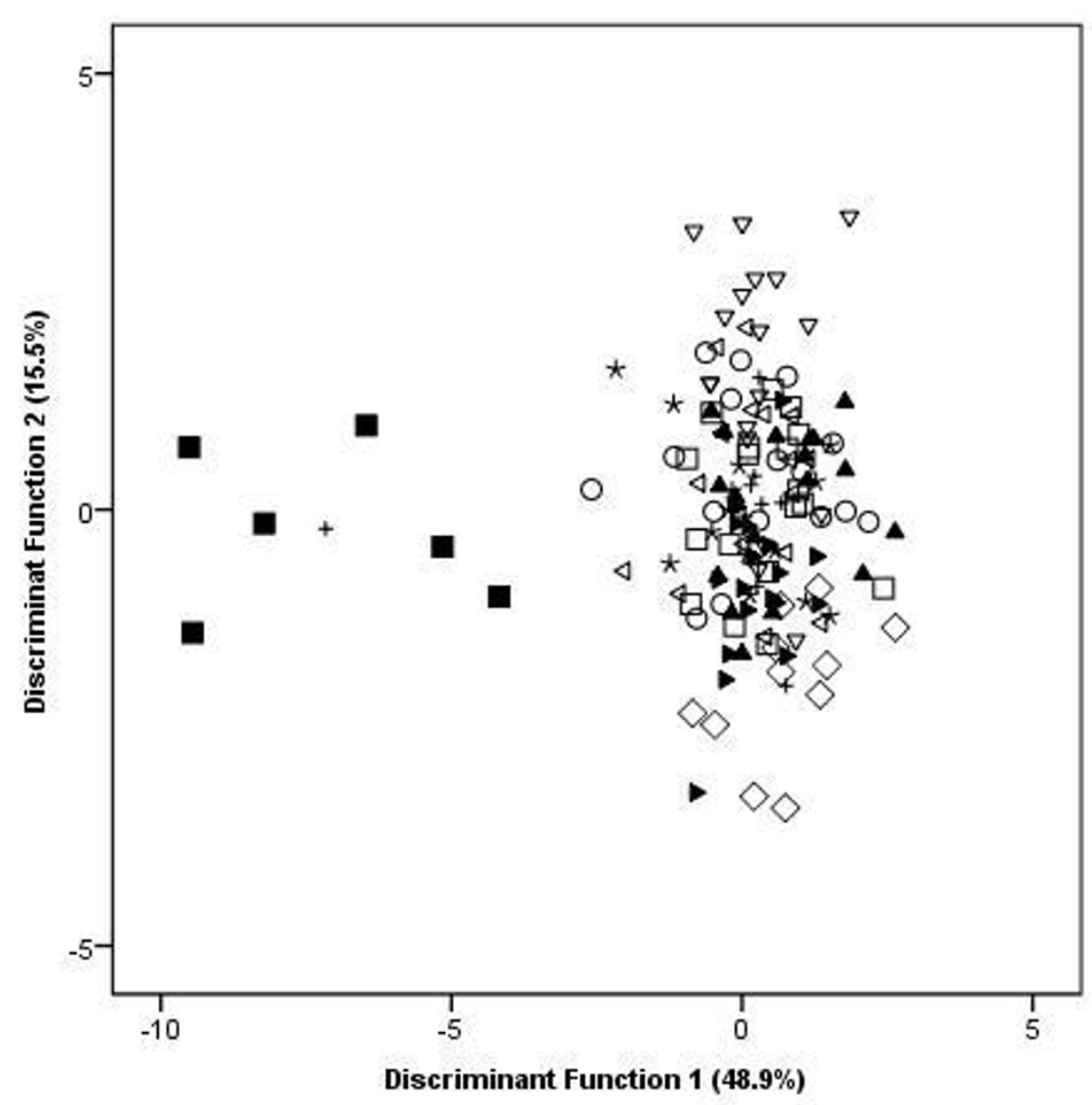

$\diamond \operatorname{Elim} 2$

Elim 3

$\Delta$ Bellville

$\nabla$ Stellenbosch

O Caledon

$\square$ Porterville

* Somerset West

$\triangleleft$ Bredasdorp

- Jonkershoek

+ Group Centroid

Figure 5 Patterns of CHC profiles of Argentine ants from different sites. Discriminant Analysis of Argentine ant cuticular hydrocarbons, based on nine principal component factors selected by Principal Component Analysis on forty CHC compounds extracted from field populations from eight sites in the Western Cape, South Africa. Ants from Elim 3 nest are significantly separated from all other ants in the remaining sites based on the CHC profiles. 
geographically separated locations [22,23]. Although this characteristic is attributed to reduced diversiy in genetic markers and nestmate recognition cues as a consequence of genetic bottleneck events experienced during introduction and establishment $[20,30]$, the release from ecological constraints (i.e. pathogens, predators, parasites) and favourable environmental conditions in the introduced range have lead to the successful expansion of incipient colonies $[6,16,30]$. Consequently leading to the formation of the geographically vast supercolonies currently observed worldwide [65].

Argentine ant populations within the introduced range often have smaller supercolonies occurring within a larger supercolony, with nests from different supercolonies sometimes separated by distances less than 30m [66,67]. This pattern is similar for the South African population with nests from the two supercolonies interspersed within each other i.e. nests from different supercolonies occurring within short distances from each other. This type of distribution pattern was best explained by van Wilgenburg et al., 2010. The initial establishment and spread of a large colony may prevent further establishment by propagules from different source populations, or if the propagules from other sources establish, their distribution will be largely limited by the population that established first [45]. This idea is supported by genetic data [68] for Elim which showed genetic structuring with "pockets" (of a divergent haplotype) surrounded by the larger supercolony (that included all other sites in this study), which is further supported our aggression data. The combination of these data from this study and the genetic data suggests that the observed aggression between ants from the two supercolonies is possibly an expression of underlying genetic differences. This is further supported by CHC congruency for the ants from the two populations. The pattern of chemical, behavioural and genetic differentiation between spatially close nests observed in this study are similar to that observed in Argentine ants from other parts of the introduced range $[30,31,35,36,42]$. The behavioural and chemical data in this study therefore offers support for at least two introductions of Argentine ants into South Africa.

Two recent studies showed the global distribution of Argentine ants is dominated by a single global dominant supercolony $[41,45]$. On continents and islands where this dominant supercolony exists, it is always the largest and most aggressive [45], displacing and outcompeting neighbouring supercolonies $[20,30,32,69,70]$. In their work, Van Wilgenburg et al (2010) included samples from Stellenbosch, Western Cape where they found that these ants do not form part of the global large supercolony and are likely to be an introduction from different source populations, as seen for other regions used in their study. Similarly, Vogel et al., 2010 found that the Stellenbosch population was highly differentiated from the six supercolonies used in their study. Both these studies suggested that South African populations are likely a primary introduction from a different source population in the native range. However, two supercolonies have been identified in the Western Cape, and although Stellenbosch forms part of the large supercolony in South Africa, it is not known whether ants from the small supercolony may also originate from a primary introduction from the native range or from a secondary introduction from other introduced supercolonies not yet identified.

\section{Conclusions}

Overall our results show that Argentine ants in the Western Cape, South Africa are unicolonial and form two supercolonies with a boundary at Elim. The observed behavioural differences between ants from the two supercolonies found in this study are possibly related to the phenotypic differences in the $\mathrm{CHC}$ profiles which are probably the expression of the underlying genetic differences. Our results are consistent with those found in earlier studies on the behaviour and colony structure of Argentine ants in other introduced ranges. These findings suggest that the similarities and differences in the phenotypic expression of $\mathrm{CHCs}$ and behaviour, among Argentine populations are important in the maintenance of unicoloniality and the formation of supercolonies.

\section{Acknowledgements}

We thank Louise Visagie for assistance in the collection of Argentine ants, Lee-Ann Noach-Pienaar for enormous help with statistical analyses, Michael McLeish for valuable comments and advice. This study was funded by the DST/NRF Centre of Excellence for Invasion Biology.

\section{Authors' contributions}

NPM conducted the sampling, experiments, analysis of data and drafted the manuscript. TCW helped develop the theoretical background for the study and the manuscript for publication. Both authors read and approved the final manuscript.

Received: 26 August 2010 Accepted: 3 February 2011

Published: 3 February 2011

\section{References}

1. Vitousek PM, D'Antonio CM, Loope LL, Rejmanek M, Westbrooks R: Introduced species: a significant component of human caused global change. New Zealand J. Ecol 1997, 21:1-16.

2. McKinney ML, Lockwood JL: Biotic homogenization: a few winners replacing many losers in the next mass extinction. TREE 1999, 14:450-453.

3. Mack RN, Simberloff D, Lonsdale WM, Evans H, Clout M, Bazzaz FA: Biotic invasions: causes, epidemiology, global consequences, and control. Ecol. Appl 2000, 10:689-710.

4. Wilson JRU, Dormontt EE, Prentis PJ, Lowe AJ, Richardson DM: Something in the way you move: dispersal pathways affect invasion success. TREE 2009, 24:136-144.

5. Bond W, Slingby P: Collapse of an ant-plant mutualism: the Argentine ant (Iridomyrmex humilis) and myrmecochorous Proteaceae. Ecology 1984, 35:1031-1037. 
6. Keane RM, Crawley MJ: Exotic plant invasions and the enemy release hypothesis. TREE 2002, 17:164-170.

7. Blackburn TM, Cassey P, Duncan RP, Evans KL, Gaston K: Avian extinction and mammalian introductions on oceanic islands. Science 2004, 305:1955-1958.

8. Pimentel D, Lach L, Zuniga R, Morrison D: Environmental and economic costs of non-indigenous species in the United States. Bioscience 2000, 50:53-65.

9. Vitousek PM, D'Antonio CM, Loope LL, Westbrooks R: Biological invasions as global environmental change. Amer. Sci 1996, 84:468-478.

10. Porter SD, Savignano DA: Invasion of polygyne fire ants decimates native ants and disrupts arthropod community. Ecology 1990, 71:2095-2106

11. Visser D, Wright MG, Giliomee JH: The effect of the Argentine ant, Linepithema humile (Mayr) (Hymenoptera: Formicidae), on flower-visiting insects of Protea nitida Mill. (Proteaceae). Afr. Entomol 1996, 4:285-287.

12. Lowe S, Browne M, Boudjelas S: 100 of the world's worst invasive alien species. Aliens 2000, 12S:1-12.

13. Chapman RF, Bourke AFG: The influence of sociality on the conservation biology of social insects. Ecol. Lett 2001, 4:650-662

14. Payne CM, Tillberg CV, Suarez AV: Recognition systems and biological invasions. Ann. Zool. Fennici 2004, 41:843-858.

15. McGlynn TP: The worldwide transfer of ants: geographical distribution and ecological invasions. J. Biogeogr 1999, 26:535-548,

16. Holway DA, Lach L, Suarez AV, Tsutsui ND, Case TJ: The causes and consequences of ant invasions. Annu. Rev. Ecol. Syst 2002, 33:181-233.

17. Elton CS: The ecology of invasions by animal and plants. Methuen. London 1958.

18. Hoffmann BD, Andersen AN, Hill GJE: Impact of an introduced ant on native rain forest invertebrates: Pheidole megacephala in monsoonal Australia. Oecologia 1999, 120:595-604.

19. White EM, Wilson JC, Clarke AR: Biotic indirect effects: a neglected concept in invasion biology. Divers. Distrib 2006, 12:443-455.

20. Tsutsui ND, Suarez AV, Holway DA, Case TJ: Reduced genetic variation and the success of an invasive species. Proc. Natl. Acad. Sci. USA 2000, 97:5948-5953.

21. Suarez AV, Holway DA, Case TJ: Patterns of spread in biological invasions dominated by long-distance jump dispersal: insights from Argentine ants. Proc. Nat. Acad. Sci. USA 2001, 98:1095-100

22. Corin SE, Abbott KL, Ritchie PA, Lester PJ: Large scale unicoloniality: the population and colony structure of the invasive Argentine ant (Linepithema humile) in New Zealand. Insect. Soc 2007, 54:275-282

23. Brandt M, van Wilgenburg E, Tsutsui ND: Global-scale analyses of chemical ecology and population genetics in the invasive Argentine ant. Mol. Ecol 2009, 18:997-1005

24. Sunamura E, Espadeler $X$, Sakamoto H, Suzuki S, Terayama M, Tatsuki S: Intercontinental Union of Argentine ants: behavioural relationships among introduced populations in Europe, North America, and Asia. Insect. Soc 2009, 56:23-27.

25. Suarez AV, Tsutsui ND, Holway DA, Case TJ: Behavioural and genetic differentiation between native and introduced populations of the Argentine ant. Biol. Invas 1999, 1:43-53.

26. Krushelnycky PD, Loope LL, Joe SM: Limiting spread of a unicolonial invasive insect and characterization of seasonal patterns of range expansion. Biol. Invas 2004, 3:47-57.

27. Errard C, Delabie J, Jourdan H, Hefetz A: Intercontinental chemical variation in the invasive ant Wasmannia auropunctata (Roger) (Hymenoptera Formicidae): a key to invasive success of a tramp species. Naturwissenschaften 2005, 92:319-323.

28. O'Dowd DJ, Green PT, Lake PS: Invasional 'meltdown' on an oceanic island. Ecol. Lett 2003, 3:812-817.

29. Abbott KL, Greaves SNJ, Ritchie PA, Lester PJ: Behaviourally and genetically distinct populations of an invasive ant provide insight into invasion history and impacts on a tropical ant community. Biol. Invas 2007, 9:453-463.

30. Giraud T, Pedersen JS, Keller L: Evolution of supercolonies: the Argentine ants of southern Europe. Proc. Nat. Acad. Sci. USA 2002, 99:3075-6079.

31. Suhr EL, McKechniel SW, O'Dowd DJ: Genetic and behavioural evidence for a city-wide supercolony of the invasive Argentine ant Linepithema humile (Mayr) (Hymenoptera: Formicidae) in south-eastern Australia. Austr. J. Entomol 2009, 48:79-83.

32. Sunamura $E$, Hatsumi $\mathrm{S}$, Karino $\mathrm{S}$, Nishisue K, Terayama M, Kitade $\mathrm{O}$, Tatsuki S: Four mutually incompatible Argentine ant supercolonies in
Japan; inferring invasion history of introduced Argentine ants from their social structure. Biol. Invas 2009, 11:2329-2339.

33. Heller NE: Colony structure in introduced and native populations of the invasive Argentine ant, Linepithema humile. Insect. Soc 2004, 51:378-386.

34. Pedersen JS, Krieger MJB, Vogel V, Giraud T, Keller L: Native supercolonies of individuals in the invasive Argentine ant. Evolution 2006, 30:782-791.

35. Tsutsui ND, Case TJ: Population genetics and colony structure of the Argentine ant (Linepithema humile) in its native and introduced ranges. Evolution 2001, 55:976-985

36. Jaquiery J, Vogel V, Keller L: Multilevel genetic analyses of two European supercolonies of the Argentine ant Linepithema humile. Mol. Ecol 2005, 2:589-598

37. Wetterer JK, Wetterer AL: A disjunct ant metacolony in Macaronesia and South Western Europe. Biol. Invas 2006, 8:1123-1129.

38. Meer Vander RK, Morel L: 'Nestmate recognition in ants, pp. 79-103.Edited by: R.K. Vander Meer, M., Breed, M. Winston, K.E. Espelie. Pheromone communication in social insects. Westview press, Boulder, CO, pp; 1998:368.

39. Lahav S, Soroker V, Hefetz A, Vander Meer RK: Direct behavioural evidence for hydrocarbons as ant recognition discriminators. Naturwissenschaften 1999, 86:66-69.

40. Singer $T L$ : Roles of hydrocarbons in the recognition systems of insects. Amer. Zool 1998, 38:394-405.

41. Vogel V, Pedersen JS, Giraud T, Krieger MJB, Keller L: The worldwide expansion of the Argentine ant. Divers. Distrib 2010, 16:170-180.

42. Björkman-Chiswell BT, van Wilgenburg E, Thomas ML, Swearer SE, Elgar MA: Absence of aggression but not nestmate recognition in an Australian population of the Argentine ant, Linepithema humile. Insect. Soc 2008, 55:207-212.

43. Caldera E, Ross K, DeHeer C, Shoemaker D: Putative native source of the invasive fire ant Solenopsis invicta in the USA. Biol. Invas 2008, 10:1457-1479.

44. Ugelvig LV, Drijfhout FP, Kronauer DJC, Boomsma JJ, Pedersen JS, Cremer S: The introduction history of invasive garden ants in Europe: integrating genetic, chemical and behavioural approaches. BMC Biology 2008, 6:1-14

45. Van Wilgenburg E, Torres CW, Tsutsui ND: The global expansion of a single ant supercolony. Evol. Appl 2010, 3:136-23.

46. Prins AJ, Robertson HG, Prins A: In Applied myrmecology: a world perspective. Edited by: Vander Meer, R.K., Jaffe, K. Cedeno, A. Pest ants in urban and agricultural areas of southern Africa. In; 1990:25-33, Westview Press, Boulder.

47. De Kock AE, Giliomee JH: A survey of the Argentine ant, Iridomyrmex humilis (Mayr), (Hymenoptera: Formicidae) in South African fynbos. J. Entomol. Soc. S. Afr 1989, 52:157-164.

48. Luruli NM: Distribution and impact of the Argentine ant Linepitheme humile (Mayr) in South Africa. MSc Thesis University of Stellenbosch 2007.

49. Carpintero S, Reyes-Lopez J, Arias De Reyna L: Impact of human dwellings on the distribution of the exotic Argentine ant: a case study in Donana National park, Spain. Biol. Cons 2003, 17:279-289.

50. Blancaford X, Gomez C: Consequences of the Argentine ant, Linepithema humile (Mayr), invasion on pollination of Euphorbia characias (L.) (Euphorbiacea). Acta Oecol 2005, 28:49-55.

51. Rowles AD, O'Dowd DJ: Interference competition by Argentine ants displaces native ants: implications for biotic resistance to invasion. Biol. Invas 2007, 9:73-85.

52. Christian CE: Consequences of a biological invasion reveal the importance of mutualism for plant communities. Nature 2001, 413:335-639.

53. Witt ABR, Giliomee JH: The impact of an invasive ant, Linepithema humile (Mayr), on the dispersal of Phylica pubescens Aiton seeds in South Africa. Afr. Entomol 2004, 12:179-185.

54. Bond W, Slingby P: Collapse of an ant-plant mutualism: the Argentine ant (Iridomyrmex humilis) and myrmecochorous Proteaceae. Ecology 1984 35:1031-1037.

55. Lach L: Argentine ants displace floral arthropods in a biodiversity hotspot. Diversity Distrib 2008, 2:281-290.

56. Liang D, Silverman J: "You are what you eat": Diet modifies cuticular hydrocarbons and nestmate recognition in the Argentine ant, Linepithema humile. Naturwissenschaften 2000, 87:412-416.

57. Buczkowski G, Kumar R, Suib SL, Silverman J: Diet-related modification of Cuticular hydrocarbon profiles of the Argentine ant, Linepithema humile, diminishes intercolony aggression. J. Chem. Ecol 2005, 31:829-843. 
58. Liang D, Blomquist GJ, Silverman J: Hydrocarbon-released nestmate aggression in the Argentine ant, Linepithema humile, following encounters with insect prey. Comp. Biochem. Physiol. B 2001, 129:871-882.

59. Torres CW, Brandt M, Tsutsui ND: The role of cuticular hydrocarbons as chemical cues in nestmate recognition in the invasive Argentine ant (Linepithema humile). Insect. Soc 2007, 54:363-373.

60. Roulston TH, Buczkowski G, Silverman J: Nestmate discrimination in ants: effects of bioassay on aggressive behaviour. Insect. Soc 2003, 50:71-79.

61. Quinn GP, Keough MJ: Experimental design and data analysis for biologists. Cambridge University Press, Cambridge, UK; 2002.

62. Clarke KR, Gorley RN: Primer v5: User Manual/Tutorial. PRIMER-E: Plymouth, UK; 2001.

63. Bray JR, Curtis JT: An ordination of the upland forest communities of Southern Wisconsin. Ecol. Monogr 1957, 27:325-349.

64. Aitchison J: The Statistical Analysis of Compositional Data. London: Chapman \& Hall. 1986.

65. Helantera H, Strassmann JE, Carillo J, Queller DC: Unicolonial ants: where do they come from, what are they, and where are they going? TREE 2009, 24:341-349.

66. Thomas ML, Payne-Makrisa CM, Suarez AV, Tsutsui ND, Holway DA: When supercolonies collide: territorial aggression in an invasive and unicolonial social insect. Mol. Ecol 2006, 7:4303-437.

67. Thomas ML, Payne-Makrisa CM, Suarez AV, Tsutsui ND, Holway DA: Contact between supercolonies elevates aggression in Argentine ants. Insect. Soc 2007, 54:135-233.

68. Lado T: Molecular ecology of introduced species in South Africa The bud gall-forming was Trichilogaster acaciaelongifoliae and the Argentine ant Linepithema humile. PhD Thesis 2008, University of Stellenbosch.

69. Hirata M, Hasegawa O, Toita T, Higashi S: Genetic relationships among populations of the Argentine ant Linepithema humile introduced into Japan. Ecol. Research 2008, 23:883-888.

70. Abril S, Gómez C: Aggressive behaviour of the two European Argentine ant supercolonies (Hymenoptera: Formicidae) towards displaced native ant species o the northeastern Iberian Peninsula. Mymercological News 2010, 14:99-108.

doi:10.1186/1472-6785-11-6

Cite this article as: Mothapo and Wossler: Behavioural and chemical evidence for multiple colonisation of the Argentine ant, Linepithema humile, in the Western Cape, South Africa. BMC Ecology 2011 11:6.

\section{Submit your next manuscript to BioMed Central and take full advantage of:}

- Convenient online submission

- Thorough peer review

- No space constraints or color figure charges

- Immediate publication on acceptance

- Inclusion in PubMed, CAS, Scopus and Google Scholar

- Research which is freely available for redistribution

Submit your manuscript at www.biomedcentral.com/submit
Biomed Central 